\title{
Where Should China's Reform of English Education Go?
}

\author{
Yongchao Zhang \\ Huanghe Science and Technology College \\ Zhengzhou, China
}

\begin{abstract}
The paper is written under a situation in which China's English education is greatly questioned. It discusses the various opinions from the society and the Internet; reviews the past 30 years' process of China's English education; objectively assesses its achievements made in this period, and put forth some suggestions for the reform of English education and the improvement of English teaching.
\end{abstract}

\author{
Keywords-English education; English teaching; China; \\ reform
}

\section{INTRODUCTION}

Recently, Beijing, capital of China, has decreased English scores for the college entrance examination. East China's Jiangsu Province has intended to let English walk out of the college entrance examination. And East China's Shandong Province has cancelled the English listening part from the college entrance examination papers. An example has been made of English by entrance examination reforms one another. What's wrong with China's English education? And where shall the reform of English teaching go? The following are discussions on what the society concerns and people talk about on Internet.

\section{VARIOUS OPINIONS ABOUT CHINA'S ENGLISH EDUCATION}

\section{A. The "Dumb English" Theory}

In recent years, much criticism and query have been directed at China's English education. All the arguments boil down to the points of "dumb English" and "failure of English education". Some argue that after a dozen of years' English learning, beginning from primary school to college, even to the doctoral or post-doctoral period, many people still cannot hear and speak, and lack in basic exchange ability.

As Professor Cheng Fangping from the Educational School of Renmin University says, no other country like ours puts English in such a high position, but gets poor effect after spending decades of years on it. It is investigated that the familiarity of the Chinese ranks second from the last in the world.

Some exaggeratedly consider that China's English education is fundamentally failed. Some strongly appeal that the authorities should abolish English courses, increase studies of Chinese culture, get rid of the children's English training classes in the society, set free the children, and save the Chinese language. Some loudly shout that English is overheated and it must return to nature. And some also publicly propose to take English as a selective course in stead of an obligatory one.

\section{B. Different Voices}

Certainly, there are also a lot of different voices: Nan Qiao, a scholar who resides in America, fiercely points out that one can not mislead education by the preconceived ideas. Nan considers that to appeal to weaken English education has no theoretical basis; the argument that English study has negative impact on Chinese learning is just a hear-say.

Li Junhe, an English teacher of special class, has put forth nine reasons against the reform of college entrance examination, from which seven points are abstracted for our discussion.

Firstly, the reform of college entrance examination should take the whole situation into consideration; the burdens of students cannot be reduced only by marginalization or a covert abolition of the English course.

Secondly, weakening the English education is a reversion against the historical tides. Over thirty years' reform and opening-up has greatly raised the foreign language quality of the Chinese people. It is very terrible to hold back such an advantageous situation.

Thirdly, one cannot put all the blame on English for the overloads of the middle school students. One cannot imagine that the middle school students will work hard at the Chinese language even if English scores for college entrance examination are reduced or cancelled. Because China's English fever is decided by the overall atmosphere of the society.

Fourthly, one cannot degrade the achievements of English teaching. As a matter of fact, nowadays, more and more Chinese young people can basically read, hear and write something in English, though they cannot speak English well. But their poor oral English can be easily improved when they stay abroad for several months or their language circumstances are favorable.

Fifthly, weakening English education is to deprive the farmers' children of their chance to study English. In case the English courses are cancelled in primary schools, or symbolically opened in middle schools, or English walks out of the college entrance examination but to the social exam organizations, it will lead to a bad outcome in which the children from ordinary families may suffer a lot. If schools 
don't open English courses, the children from the rich can go to English training classes after school, but the children from farmers cannot do the same way because of their poor conditions. When they go to college, they can not compete with those who have a higher English level.

Sixthly, the burden of English teaching might be lifted to colleges and universities. If the English scores for the college entrance examination are changed into 100 points from the original 150 points, or the English scores are not taken into account in later days, and English grades are evaluated by the social organizations, it will greatly lower English levels in the middle schools and this means the heavy burden of English teaching will be shifted to colleges and universities. Therefore, once the students come into the university, they spend no time in learning other subjects but English to pass the CET-4 or CET-6, actually it is no good for the university teaching.

Seventhly, the students will miss the best time to learn English. The best time for one to learn a foreign language is the period of primary and middle schools, especially the period of middle schools, or the age of 10 to 20 . After this age period, it is no easy job to learn a foreign language. Those who are at 30 or 40 might have little possibility to succeed.

\section{Views from the Top Designers}

Professor Chen Lin, head of the Expert Panel for the National English Curriculum Criteria by China Ministry of Education, proposed to resist utilitarianism in English teaching. In his opinion, not only the English education but the whole education in China is facing a crisis, the root of which is not because of foreign language learning but of the utilitarianism in the minds of parents and their children. This has posed a social problem. Many parents adhere to the "starting line theory," and don't want their children to loose at the starting line. So they have to spend much money on a variety of training courses including English, singing, dancing and specialties. What's more, in order to have the chance of entering a better school, their children have to attend various English exams, which obviously violate the stipulations of the Ministry of Education, but what else can the parents do except compelling their children to learn a foreign language or other specialties.

Children's language ability can be improved even faster if they learn a language earlier. The development of language will promote their thinking ability, as people think by means of language. But learning a foreign language should take the right direction. If the methods are correct, the earlier the children begin to learn a foreign language, the better the result will be; if incorrect, the earlier the worse. Once the children's interest is destroyed, they will hate English.

What is the result if English is cancelled from the national primary curriculum? Chen Lin thinks that it is impossible. Once the Ministry of Education cancels the courses, who will be the happiest? Of cause the foreign language training firms. Immediately will appear a large batch of foreign language training classes in the society, and their business must be very good. As the parents haven't changed their concept and the "starting line" theory still exists. There is no lower demand for foreign languages, for the sake of better primary schools, better middle schools and better universities.

He doesn't agree with the idea of reducing the proportion of foreign language education in order to improve the national Chinese level. He thinks that the national Chinese level has been reduced indeed, and should be improved with great efforts. But the reduction of the Chinese level in the whole society is not caused by learning more foreign language. In terms of school education, the educational concept of utilitarianism makes children over diffuse their energies, they have no time to focus on learning Chinese and reading good works. In addition, the children get in touch with too many electronic products and often indulge in electronic game, these are not conducive to the physical and mental health. Moreover, the information that the mass media spread are mixed up with more bad things, children's TV programs are produced in a rough way, good shows are too few. These are the reasons for the reduction of our Chinese level, which have nothing to do with the proportion of foreign language learning. The students who are good at Chinese learning are also good at learning foreign language. On the other hand, the students who learn foreign language well generally learn Chinese well, too. This is a common phenomenon, recognized by many linguists. In terms of language learning, if the students have talents or like it, they can learn both Chinese and English well. We cannot say that the low level of Chinese is caused by learning too much foreign language. The learning of a foreign language and of a native language can complement each other rather than conflict with each other. This has also been proved by researches on linguistics, psycholinguistics and children psychology.

As for some persons' proposing that English be a selective course in stead of the compulsory one as before, Chen neither opposes it nor supports it. In his opinion, if it was adopted, the existing English teaching system would be disturbed. For example, some students would not learn English in the primary schools but others would. Whether should they be divided into different classes when they went to junior middle schools? How would teachers teach the students at different English levels? How to link up junior middle schools with senior middle schools or colleges? The problem would be very serious. One may think of setting English as a selective course, but must imagine what a situation it would lead to in the near future.

$\mathrm{He}$ is not against the idea that the minimum English passing scores should be deduced in the college entrance examination, but against reducing the English courses because of deducing English scores for college entrance examination. Instead, English courses should be offered according to the National English curriculum standards. For the college students, foreign language is an important tool to read a wide range of foreign professional books. If one has poor English, his further study will be limited. So requirements for English learning can not be lowered even if the minimum English passing scores for the national college entrance examination are deduced. 
In the light of the proposal raised by some deputies of China National People's Congress that foreign languages should be abolished from the examinations for civil servants and postgraduates, Chen considers that it would run a too high risk. Due to historical reasons, English has been an international language and an important tool to communicate. The foreign language level has been part of soft power for a country. Take India for example. As English is one of India's official languages, thanks to their good mastery of English, a rapid development has been made in its information engineering field. Nowadays, China's opening up to the outside world has constantly been expanded and international exchanges and cooperation have continuously been increased, which calls for the whole nation to raise foreign language level. The leading cadres are to be trained in special training classes for English so as to decrease their dependence on interpreters or translators in daily exchanges. If the English examinations for civil servants and postgraduates were abolished, there would be some negative effects.

To sum up, for China's English education, there are various remarks. Some are dissenting voices, the others are supportive ones. English education is part of the national quality education and is a long-term and gradual process. There should be no profit-oriented thinking. One can not expect to solve the problem and reach the ideal target in such a short period as a decade or two. As everyone knows, English education in Japan, South Korea and other countries in the world is still heating up day by day. However, China's English education has indeed much to be improved anyway.

\section{An OBJeCtive AsSessment of ChinA's ENGLish EDUCATION}

\section{A. China's English Fever}

The quietly rising of "English fever" with China's reform and opening-up has been lasting for over 30 years in the country without a little decrease of its hotness, which has proved the high position of English in people's minds. The continuous development of China's English education just complies with the needs of progress of the times and the society, which can be seen by the historical process of China's English education.

\section{B. The Evolution of China's English Education}

In 1983, an English exam became a must for the entrance from junior middles schools into senior middle schools; in 1984, English was included formally in the subjects of college entrance examinations ; in September 1987, China began to implement CET-4; in January 1989, China began to implement CET-6. Subsequently, most Chinese universities stipulated that students who could not pass CET-4 will not get university degree certificate; in 1992, due to the reform of subject division system, English suddenly began to upgrade from a compulsory subject to one of the three main subjects for college entrance examinations; about the year 1998, the situation that students began to learn English from junior middle schools was changed into one that students began to learn English from primary schools. Later on, some children even began to learn English from their kindergarten stage; in 1999, the national English exams for professional tittles began to be implemented in the country; in 2001, the Ministry of Education issued the "English Curriculum Criteria for Full-time Compulsory Education" ( the test draft), and the English course was advanced to the third grade ; from 2002, many universities announced in succession that the CET-4 certificate was separated from the degree certificate, but until 2007, there was still controversy. Despite the CET-4 certificate was not linked with the degree certificate, the survey showed that the CET-4 and CET-6 certificate-holding rate reached 95 percent in students-held certificates, which topped the list; in 2006, China's largest foreign language training agency New Oriental was listed on New York Stock Exchange.

\section{The Achievements of China's English Education}

Keeping the whole of China in view, from "Follow Me", "Crazy English," to "Bilingual Baby," hundreds of millions of Chinese people's enthusiasm for learning English has never been abated. It is true that the achievements in English teaching gained by universities and middle schools in the past 30 years are great, because it makes hundreds of millions of Chinese have their English level improved. China's English education has greatly enhanced the nation's language quality and has also brought up large numbers of qualified foreign language talents in all circles and translators who serve the diplomacy, foreign affairs, foreign trade and so on. With the popularization of English as a communicative tool in the world, China has closely been linked with other countries over the world. Wisdom and wealth of the human community has been flowing freely every where, and commonly multiplied and updated. At the same time, our Chinese language has also become new "English" opposite the big ocean.

\section{The Development of English Education through Arguments}

Indeed, most of the Chinese English learners have a secret anguish in their minds, which is reflected by the serious disjoint between learning ability and practical ability. As people say, "Learning English is a must whether there is any use or not; one cannot use English whether he or she learns English or not."

Some people hold a supportive voice that, as an international communication tool, English does not belong to a country or a nation any longer. It is popularized all over the world at an unprecedented speed. Why not try hard to learn it?

Some have a negative voice that, under the backdrop of exam-oriented education in China, a common student may spend more than $50 \%$ of his or her energy on English, whereas most students' Chinese competence is getting worse. It is not bad to learn English, but it does not mean that English exams prevail over in our daily life. Why do we need to attach too much importance to English learning in China?

Debates have never been stopped so far. But in reality, more and more people find that those who have mastered English will have more opportunities to obtain good jobs. 
Free communication with the world can only be achieved by speaking and writing idiomatic English.

\section{Thoughts ABOut Restructuring ENGLish TeACHING}

\section{A. The Age}

The age to learn English should be reformed. The result will be almost the similar whether one begins to learn English at ten yeas old or below. It is a big waste of time and money for those who start learning English at a very early age, because what they have learned would have been easily forgotten. And a reading disorder may arise due to the confusion between the Chinese alphabetic writing and the English letters. Numerous studies have shown that those who have a solid basis of their mother tongue will learn foreign languages faster and better than those who haven't. Therefore it is correct for the related authorities in Beijing to have a discussion on whether or not to open English classes for the first and second graders in primary schools.

\section{B. The Approach}

The way children learn English should be improved. The way children learn English is totally different from adults. With a better basis of their mother tongue, adults can compare English with their mother language by using similar syntax rules when learning it, which will promote understanding of the language. However, it would be very ineffective for children to learn a foreign language by using the "translation approach" (i.e. using Chinese to teach English). For children to learn a foreign language, a natural gain method should be used so as to make the children learn it easy just like their learning to say, without any necessity to memorize words, nor need to learn grammar rules.

\section{The Textbook}

The English textbooks should be improved. First of all, there should be no Chinese characters in the English textbooks. The English textbooks for foreign students usually have no other language but English in other parts of the world. Why is the English textbook in China an exception? In addition, English should not be taught in the "Chinese textbook style". In the United States, all the textbooks teaching American students to learn Chinese take China as the scene, such as how to say hello to a Chinese, how to get along with the Chinese students, how to perform in class, how to take a bus, and so on. However, English textbooks in China do not include how a Chinese says hello to an American or how to live in America. How can one learn a language well if he or she doesn't learn the culture and lifestyle of that country?

\section{The Teaching}

The way of English teaching should be bettered. The immersion mode is currently the most advanced way in foreign language teaching. This approach is to teach the subjects besides languages, such as mathematics, biology, physics, chemistry, geography and so on. This makes the students learn the language with a certain need. The students can master academic language with the assistance of academic knowledge. Thus, such an embarrassing situation would not happen that a Chinese student can not express the simple words "slope", "rectangular solid", or "fraction line" in English.

\section{E. The Class}

The classroom teaching should be optimized, burdens on students decreased and efficiency increased. In English teaching, one should take the new idea of curriculum reform as a guide, analyze the curriculum standards carefully, and grasp and apply the following teaching concepts flexibly.

Be geared to all the students, and lay a good foundation for students' all-round and lifelong development. In English learning, teachers should encourage students to speak English boldly, take a tolerant attitude towards their mistakes and errors, provide opportunities for students to study independently and communicate with each other as much as possible, and develop their listening, speaking, reading and writing comprehensive language skills through practice and discussion.

Pay attention to students' emotion, and create a relaxed, democratic and harmonious teaching atmosphere. First of all, respect each student, encourage them to try in study, protect their self-esteem and motivation, and combine English teaching with emotional teaching organically. Secondly, one must carry out a variety of learning activities to enable students to experience the sense of accomplishment and honor and the spirit of cooperation amid the pleased atmosphere of learning from each other and helping each other. What's more, teachers can reflect over the learning process and strategies, experience the joy of learning together with the students, with a benefit to both teaching and learning. If we insist on this for a long time, we can surely walk into students' hearts and become their good teachers and helpful friends.

Broaden students' view, adjust their learning strategies and guide them to develop a self-study habit. On the one hand, teachers should enable students to learn and understand more foreign culture and history, and to experience the exotic customs, so as to enhance their awareness and ability of cross-cultural communication. For example, they can read classics, tell stories, guide tourists and do other activities in order to extend their eyes and enrich their knowledge. On the other hand, teachers should help students adjust learning strategies, and strengthen the guidance of learning method to let them develop a good study habit. One should not only focus on his or her own instructional design, the implementation of teaching theory, and the optimization of classroom teaching, but also pay more attention to the students' learning attitudes and strategies. It is more important to teach students how to learn than to teach them what to learn. A good teacher should let students themselves to do whatever they can, thus highlighting the dominant position of them and giving them more space of thinking imagination. This will not only help reduce the academic burden on students and their mental stress, but also help cultivate their innovative spirit and practical ability, and create a class full of vigor and vitality. 


\section{F. The Practice}

Rich and colorful English practice activities should be carried out to stimulate students' interest in learning English.

1) Having performance of short dramas. Students shall be asked to write some short dramas by themselves in their free time. The students' awareness of active participation can be significantly enhanced since they play the roles of directors, screenwriters, protagonists, art designers, and narrators etc. In the course of drama writing, the students draw on all useful opinions and pool all the brains and brawn. In the meanwhile, they put word fraises and sentences they have learned in usual days into the performance of short dramas. In this way, they can learn knowledge a midst entertainment and relaxation.

2) Reading classics. Reading classics is helpful not only to broaden their field of vision, to expand vocabulary, to learn the history and customs of foreign countries, but also to learn authentic foreign languages, to feel the unique style of British and American fictions. Many classics can be used as students' extensive reading materials, for example, The Three Musketeers, Notre Dame de Paris, Tale of Two Cities, War and Peace, Count of Monte Cristo, Jane Eyre, The Old Man and the Sea ,etc.

3) Setting up writing paradise. It is a highlight to train and develop writing skills for English teaching. In order to stimulate students' creative desires, writing paradise should be set up in English teaching, aiming at encouraging the students to write more and practice more. Teachers can help modify and submit some excellent writings to magazines or journals for publication, therefore, making the students have more interest and confidence in writing.

4) Building English wide angle. To stimulate students' interest and enthusiasm for learning English, schools can build a wide angle platform for their talent show, on which students can perform a piece of the film Titanic, recite Tagore's poems, sing Scottish songs, and do Latin dancing, so as to enjoy the pleasure brought by learning English.

\section{CONCLUSION}

Over the past 30 years, English from the other side of the great ocean has inevitably embedded in Chinese people's life. Obviously, the "English fever" has been brought up by China's reform and opening-up, which has also boosted the prosperity of English education in China and, in turn, the development of English education has greatly promoted China's opening-up to the outside world.

Different people have different opinions on where English teaching reform should go. The above is just my personal reflections on English teaching reform though it may not be scientific and accurate. But I firmly believe that China's English teaching will certainly make great progress so long as our academic colleagues have a sense of responsibility and dedication to our education and work harder at observation, reflection and summary.

\section{REFERENCES}

[1] Xuming, Wang. The Children's English Learning Should Be Braked [I]. www.eduthought.net.Oct.25,2013.

[2] Siling, Luo. The Examination English Also Has Some Reasons to Be Loved [I]. www.eduthought.net.Nov.6,2013.

[3] Zhongyi, Cheng. The Overheated English Should Return to Nature [I]. www.eduthought.net.Nov.11,2013.

[4] Qiao, Nan. Don't Mislead the Education by the Preconceived Ideas [I]. www.eduthought.net.Nov.6,2013.

[5] Junhe, Li. Nine Reasons against the English Reform on College Entrance Examination [I]. www.eduthought.net.Nov.31,2013.

[6] A Short History of China's English Education [I]. www.eduthought.net.Oct.25,2013.

[7] Daye, wang. A Compulsory English Course Should Be Changed into a Selective One [I]. www.eduthought.net.Oct.27,2013.

[8] Chaomeng, Luo. Japan's English Education Has Being Heated up through Climbing [I]. www.eduthought.net.Nov.15,2013.

[9] Lin, Chen. Resisting Utilitarianism in English Teaching[I]. www.eduthought.net.Nov.5,2013. 